\title{
Pertanggungjawaban Hukum atas Keterlambatan Pemberitahuan Akuisisi Asing kepada Komisi Pengawas Persaingan Usaha
}

\author{
Muchamad Arifin \\ muchamad.arifin.mail@gmail.com
}

\begin{abstract}
This study examines the authority of KPPU (Indonesian Business Competition Supervisory Commission) in the case of late notification of the acquisition of Woongjin shares by Toray Materials. The acquisition is carried out by a foreign company that is not domiciled in Indonesia, so the act is outside the jurisdiction of the Republic of Indonesia. This study also examines the legal liability of Toray Materials for the late notice of Woongjin share acquisition. Toray Materials reasoned that the delay is due to their having insufficient information about the laws and regulations in Indonesia. This study is normative legal research using a legislative approach and a case-study approach. Based on the results, we find that KPPU has the authority over the corporate action by Toray Materials in performing their acquisition of Woongjin shares. Based on the principle of legal duty by mistake element, Toray Materials has the legal responsibility for their action. Their mistake is a form of negligence.
\end{abstract}

Keywords: Business competition; share acquisition

\begin{abstract}
Abstrak
Penelitian ini mengkaji mengenai kewenangan KPPU dalam kasus keterlambatan pemberitahuan atas tindakan akuisisi saham perusahaan Woongjin yang dilakukan oleh Toray Materials. Akuisisi tersebut dilakukan oleh perusahaan asing yang tidak berkedudukan di Indonesia, sehingga tindakan akuisisi tersebut dilakukan di luar wilayah hukum Negara Republik Indonesia. Penelitian ini juga mengkaji tentang pertanggungjawaban hukum Toray Materials atas keterlambatan pemberitahuan/ notifikasi tindakan akusisi saham Woongjin. Toray Materials beralasan bahwa keterlambatan tersebut dikarenakan Toray Materials tidak mempunyai informasi yang cukup tentang peraturan perundangundangan di Indonesia. Penelitian ini merupakan penilitian hukum normatif dengan menggunakan pendekatan perundang-undangan dan pendekatan kasus. Berdasarkan hasil penelitian dapat disimpulkan bahwa, KPPU memiliki kewenangan terhadap tindakan korporasi yang dilakukan oleh Toray Materials berupa pengambilalihan (akuisisi) saham Woongjin. Berdasarkan prinsip pertanggung jawaban berdasarkan unsur kesalahan, Toray Materials memiliki pertanggung jawaban secara hukum atas perbuatannya. Kesalahan yang dilakukan oleh Toray Materials merupakan kesalahan dalam bentuk kelalain.
\end{abstract}

Kata-kata Kunci: Persaingan usaha; pengambilalihan saham 


\section{Pendahuluan}

Pada 2 Februari 2016, Majelis Komisi Pengawas Persaingan Usaha (KPPU) memeriksa Toray Advance Materials Korea Inc. (Toray Materials) sebagai pihak Terlapor. Dalam pemeriksaan tersebut Toray Materials diduga melakukan pelanggaran terhadap ketentuan Pasal 29 Undang-Undang Nomor 5 Tahun 1999 tentang Larangan Praktek Monopoli dan Persaingan Usaha Tidak Sehat (UU No.5/1999) juncto Pasal 6 Peraturan Pemerintah Nomor 57 Tahun 2010 tentang Penggabungan atau Peleburan Badan Usaha dan Pengambilalihan Saham Perusahaan yang dapat mengakibatkan terjadinya Praktik Monopoli dan Persaingan Usaha Tidak Sehat (PP No. 57/2010).

Setelah dilakukan pemeriksaan, Majelis KPPU memutuskan bahwa Toray Materials telah terbukti secara sah dan meyakinkan melanggar ketentuan Pasal 29 UU No. 5/1999 juncto Pasal 6 PP No. 57/2010. Akibat dari pelanggaran terhadap ketentuan tersebut, Toray Materials dihukum untuk membayar denda pelanggaran di bidang persaingan usaha sebesar Rp. 2.000.000.000,-. ${ }^{1}$ Keputusan tersebut sebagaimana yang tertuang dalam Putusan Perkara Nomor 17/KPPU-M/2015, yang dibacakan pada 11 Maret 2016. ${ }^{2}$

Putusan Majelis KPPU di atas bermula dari tindakan korporasi yang dilakukan oleh Toray Materials berupa pengambilalihan (akuisisi) saham perusahaan Woongjin Chemical Co. Ltd. (Woongjin) sebesar 56.21\%. ${ }^{3}$ Mengetahui bahwa tindakan akuisisi tersebut wajib dilakukan pemberitahuan/ notifikasi kepada otoritas pengawas persaingan usaha di Indonesia yakni KPPU, Direktur Toray Materials pada 21 Maret 2014 menyampaikan pemberitahuan/ notifikasi kepada KPPU.4 Pemberitahuan/ notifikasi tersebut kemudian ditindaklanjuti oleh KPPU dengan dilakukan penyelidikan oleh Tim Investigator KPPU.

\footnotetext{
"Siaran Pers Pembacaan Putusan Perkara Nomor 17/KPPU-M/2015", http://www.kppu.go.id/id/blog/2016/03/siaran-pers-pembacaan-putusan-perkara-nomor-17kppu-m2015/ diakses pada tanggal 27 September 2017.

${ }^{2}$ Ibid.

3 Salinan Putusan Majelis Komisi Pengawas Persaingan Usaha Republik Indonesia, tentang Dugaan Pelanggaran Pasal 29 Undang-Undang Nomor 5 Tahun 1999 Juncto. Pasal 6 Peraturan Pemerintah Nomor 57 Tahun 2010 dalam Pengambilalihan Saham (Akuisisi) Perusahaan Woongjin Chemical Co. oleh Toray Advanced Materials Korea Inc., Nomor 17/KPPU-M/2015, hlm. 4

${ }^{4}$ Ibid., hlm. 22
} 
Berdasarkan hasil penyelidikan, proses akuisisi saham perusahaan Woongjin oleh Toray Materials diselesaikan pada 28 Februari 2014..$^{5}$ Menurut tim investigasi KPPU, seharusnya batas akhir kewajiban Toray Materials menyampaikan pemberitahuan/ notifikasi tersebut yaitu 30 hari sejak tanggal berlakunya akuisisi yang jatuh pada 11 April 2014. ${ }^{6}$ Hal tersebut didasarkan pada ketentuan Pasal 29 ayat (1) UU No. 5/1999. Oleh karena itu, investigator KPPU menyimpulkan bahwa Toray Materials terlambat melakukan pemberitahuan/ notifikasi tindakan akuisisi saham Woongjin selama 5 hari kerja, sehingga Toray Materials diduga telah melakukan pelanggaran terhadap ketentuan Pasal 29 UU No. 5/1999 juncto. Pasal 6 PP No. $57 / 2010 .^{7}$

Pada saat berlangsungnya pemeriksaan yang dilakukan oleh Majelis KPPU, pihak Terlapor yakni Toray Materials beralasan bahwa keterlambatan pemberitahuan/ notifikasi atas tindakan akuisisi tersebut, karena mereka tidak mempunyai informasi yang cukup tentang peraturan di Indonesia. ${ }^{8}$ Bahkan, kesimpulan yang dibuat dan disampaikan pihak Toray Materials pada saat pemeriksaan menyatakan bahwa, Toray Materials tidak wajib untuk melakukan notifikasi kepada Komisi karena yurisdiksi yang berlaku untuk tindakan pengambilalihan saham tersebut adalah yurisdiksi negara Korea bukan Indonesia. ${ }^{9}$

Toray Materials dan Woongjin merupakan perusahaan asing yang berkedudukan di Korea Selatan, tetapi kedua perusahaan tersebut secara tidak langsung melakukan kegiatan usaha di Indonesia melalui perusahaan lain yang dikendalikannya. ${ }^{10}$ Toray Materials melakukan kegiatan usaha di Indonesia melalui perusahaan yang dikendalikannya yaitu PT. Polytech Jakarta (65\% sahamnya dimiliki oleh Toray Materials), sedangkan Woonjin juga melakukan kegiatan usaha

${ }^{5}$ Ibid.

${ }^{6}$ Ibid., hlm. 33

${ }^{7}$ Ibid.

8 Rio Sandy Pradana, "Didenda, Toray Gugat KPPU", http://koran.bisnis.com/read/ 20161021/439/594567/didenda-toray-gugat-kppu diakses pada tanggal 27 September 2017

9 Salinan Putusan Majelis Komisi Pengawas Persaingan Usaha Republik Indonesia, tentang Dugaan Pelanggaran Pasal 29 ... Op. Cit., hlm. 66

10 Sinar Putri S. Utami, "Toray Advanced tetap Dihukum Denda Rp 2 M ke KPPU", http://nasional.kontan.co.id/news/toray-advanced-tetap-dihukum-denda-rp-2-m-ke-kppu diakses pada tanggal 27 September 2017 
di Indonesia melalui perusahaan yang dikendalikannya yaitu, PT. Woongjin Textile. ${ }^{11}$ Toray Materials sendiri merupakan perusahaan yang 100\% kepemilikan sahamnya dimiliki oleh perusahaan induk tertingginya yaitu Toray Industries Inc., yang juga berkedudukan di Korea Selatan. ${ }^{12}$ Berkedudukan sebagai perusahaan induk, Toray Industries Inc. juga memiliki beberapa anak perusahaan lain yang berkedudukan dan melakukan kegiatan usaha di Indonesia.

Berdasarkan uraian di atas, hal yang menarik untuk dikaji adalah terkait ruang lingkup kewenangan KPPU terhadap tindakan akuisisi saham perusahaan Woongjin yang dilakukan oleh Toray Materials. Sebagaimana disampaikan sebelumnya, tindakan akuisisi tersebut dilakukan oleh perusahaan asing (tidak berkedudukan di Indonesia), dan tindakan akuisisinya pun juga dilakukan di luar wilayah hukum Negara Republik Indonesia. Selain itu, Toray Materials beralasan bahwa keterlambatan tersebut dikarenakan Toray Materials tidak mempunyai informasi yang cukup tentang peraturan di Indonesia, khususnya terkait dengan adanya kewajiban untuk memberitahukan tindakan akusisi tersebut kepada KPPU. Oleh karena itu perlu dikaji pula mengenai ada atau tidaknya pertanggungjawaban hukum Toray Materials terhadap keterlambatan pemberitahuan/ notifikasi tindakan akusisi saham Woongjin.

\section{Rumusan Masalah}

Adapapun permasalahan dalam penelitian ini adalah, sebagai berikut: pertama, bagaimanakah kewenangan Komisi Pengawas Persaingan Usaha (KPPU) terhadap tindakan akuisisi saham Woongjin oleh Toray Materials yang dilakukan di luar wilayah hukum Republik Indonesia? Kedua, bagaimanakah pertanggaungjawaban hukum Toray Materials atas keterlambatan pemberitahuan/ notifikasi tindakan akusisi saham Woongiin?

\section{Tujuan Penelitian}

Berdasarkan rumusan masalah di atas, tujuan dari penelitian ini adalah sebagai berikut: pertama, untuk menganalisis kewenangan Komisi Pengawas

\footnotetext{
Op. Cit., hlm 14.

${ }^{11}$ Salinan Putusan Majelis Komisi Pengawas Persaingan Usaha Republik Indonesia, tentang Dugaan..., 12 Ibid., hlm. 13
} 
Persaingan Usaha (KPPU) terhadap tindakan akuisisi saham Woongjin oleh Toray Materials yang dilakukan di luar wilayah hukum Republik Indonesia. Kedua, menganalisis pertanggaungjawaban hukum Toray Materials atas keterlambatan pemberitahuan/ notifikasi tindakan akusisi saham Woongjin.

\section{Metode Penelitian}

Penelitian ini merupakan penelitian hukum yang termasuk dalam tipologi penilitian hukum normatif. Bahan hukum yang digunakan dalam penelitian ini terdiri dari bahan hukum primer dan bahan hukum sekunder. Pengumpulan bahan hukum dilakukan melalui studi dokumen yang kemudian dilakukan analisis secara kualitatif. Adapun pendekatan yang dilakukan dalam penelitian ini adalah pendekatan perundang-undangan dan pendekatan kasus. Hasil dari penelitian ini kemudian disajikan dalam bentuk deskriptif kualitatif.

\section{Hasil Penelitian dan Pembahasan}

Kewenangan Komisi Pengawas Persaingan Usaha (KPPU) terhadap Tindakan Akuisisi Saham Woongjin yang dilakukan oleh Toray Materials

Pengambilalihan atau akuisisi adalah bentuk pengambilalihan kepemilikan perusahaan oleh pihak pengakuisisi, yang mengakibatkan berpindahnya kendali atas perusahaan yang diambil alih tersebut. ${ }^{13}$ Dalam tindakan akuisisi perusahaan, saham yang dipegang oleh pengakuisisi setelah tindakan akuisisi tersebut paling sedikit 51\%, sebab jika kurang dari persentase tersebut maka perusahaan target tidak akan bisa dikendalikan. ${ }^{14}$ Perbuatan hukum akuisisi pada prinsipnya tidak mengakibatkan perusahaan/perseroan yang diambil alih sahamnya mejadi bubar atau berakhir. ${ }^{15}$ Oleh karena itu, perusahaan/perseroan yang diakuisisi tetap eksis, hanya saja pengendalian atas perusahaan/perseroan tersebut beralih kepada pengakuisisi.

\footnotetext{
${ }^{13}$ Susanti Adi Nugroho, Hukum Persaingan Usaha Di Indonesia, Dalam Teori Dan Praktik. Serta Penerapan Hukumnya, Penerbit Kencana, Jakarta, 2012, hlm. 480

${ }^{14}$ Ibid., hlm. 486

15 M. Yahya Harahap, Hukum Perseroan Terbatas, Penerbit Sinar Grafika, Jakarta, 2015, hlm. 509
} 
Dalam persaingan usaha, aktifitas merger (penggabungan, peleburan, dan pengambilalihan/akusisi saham) memiliki keterkaitan erat dengan penyalahgunaan posisi dominan dalam pasar yang dapat menimbulkan praktek monopoli dan persaingan usaha tidak sehat. Dalam hal suatu perusahaan melakukan akuisisi terhadap perusahaan lain, di mana kedua perusahaan tersebut bergerak dalam bidang usaha yang sama, maka pangsa pasar kedua perusahaan tersebut akan bersatu dan membentuk gabungan pangsa pasar yang lebih besar. ${ }^{16}$ Kondisi tersebut dapat mengakibatkan perusahaan hasil merger tersebut meraih atau memperkuat posisi dominan dalam pasar, dan peluang penyalahgunaan posisi dominan tersebut akan semakin besar. ${ }^{17}$

Semakin kuatnya posisi dominan yang dimiliki oleh suatu perusahaan hasil merger (penggabungan, peleburan, dan pengambilalihan/ akuisisi saham) di dalam pasar maka, potensi terjadinya hambatan masuk pasar bagi pelaku usaha baru pun akan semakin besar. ${ }^{18}$ Hal tersebut tentu akan merusak iklim persaingan usaha, sebab jumlah pesaing di dalam pasar akan semakin sedikit, dan mengakibatkan semakin kecil pula fleksibilitas persaingan di pasar yang bersangkutan. ${ }^{19}$ Oleh karena itu, aktifitas merger perlu mendapatkan kontrol dari otoritas persaingan usaha yaitu KPPU, karena aktifitas merger yang menimbulkan persaingan usaha tidak sehat pada akhirnya merugikan masyarakat dan kepentingan umum. ${ }^{20}$

Pasal 28 ayat (2) UU No.5/1999 menentukan bahwa, pelaku usaha dilarang melakukan pengambilalihan saham perusahaan lain apabila tindakan tersebut dapat mengakibatkan terjadinya praktek monopoli dan atau persaingan usaha tidak sehat. Ketentuan Pasal 28 ayat (2) tersebut pada dasarnya bersifat rule of reason, maksudnya adalah tindakan akuisisi saham perusahaan pada prinsipnya diperkenankan asalkan tidak mengurangi persaingan secara substansial.21

Dalam perkara pengambilalihan/akuisisi saham Woongin oleh Toray Materials, Majelis KPPU memutus bahwa Toray Materials telah terbukti secara sah

16 Andi Fahmi Lubis et. al., Hukum Persaingan Usaha Antara Teks \& Konteks, Penerbit Komisi Pengawas Persaingan Usaha (KPPU), Jakarta, 2009, hlm. 197

${ }_{17}$ Ibid., hlm. 198

18 Ibid., hlm. 192

${ }^{19}$ Ibid.

${ }^{20}$ Ibid.

${ }^{21}$ Rachmadi Usman, Hukum Persaingan Usaba Di Indonesia, Penerbit Sinar Grafika, Jakarta, 2013, hlm. 643 
dan meyakinkan melanggar ketentuan Pasal 29 UU No. 5/1999 Juncto Pasal 6 PP No. 57/2010.22 Pasal 29 ayat (1) UU No. 5/1999 mengatur bahwa, akuisisi saham yang berakibat nilai aset dan atau nilai penjualannya melebihi jumlah tertentu, wajib diberitahukan kepada Komisi (KPPU), selambat lambatnya 30 hari sejak tanggal pengambilalihan tersebut. Ketentuan tersebut pada dasarnya merupakan bentuk kontrol untuk menghindari tindakan akuisisi saham oleh pelaku usaha yang mengarah kepada anti persaingan. Perusahaan wajib menyampaikan pemberitahuan/notifikasi kepada KPPU apabila perusahaan hasil akuisisi saham memiliki nilai aset gabungan melebihi Rp. 2.500.000.000.000,-, dan nilai penjualan gabungan melebihi Rp. 5.000.000.000.000,-,.23 Adapun sanksi atas pelanggaran kewajiban menyampaikan pemberitahuan/ notifikasi tindakan akuisisi saham diatur secara tegas dalam Pasal 6 PP No. 57/2010, sebagai berikut:

“Dalam hal Pelaku Usaha tidak menyampaikan pemberitahuan tertulis sebagaimana dimaksud dalam Pasal 5 ayat (1) dan ayat (3), Pelaku Usaha dikenakan sanksi berupa denda administratif sebesar Rp. 1.000.000.000,00 (satu miliar rupiah) untuk setiap hari keterlambatan, dengan ketentuan denda administratif secara keseluruhan paling tinggi sebesar Rp. 25.000.000.000,00 (dua puluh lima miliar rupiah)."

Pada saat pemeriksaan, pihak Toray Materials menyatakan bahwa dirinya tidak wajib untuk melakukan notifikasi kepada Komisi karena yurisdiksi yang berlaku untuk tindakan pengambilalihan saham tersebut adalah yurisdiksi negara Korea bukan Indonesia. Dalam pertimbangannya, Majelis KPPU menyatakan bahwa tindakan akuisisi saham Woongjin oleh Toray Materials merupakan pengambilalihan/akuisisi saham yang diatur dalam Pasal 29 ayat (1) UU No. 5/1999. ${ }^{24}$ Oleh karena itu, tindakan akuisisi saham Woongjin tersebut tunduk pada

${ }^{22}$ Lihat Petitum angka 1 dalam Salinan Putusan Majelis Komisi Pengawas Persaingan Usaha Republik Indonesia, tentang Dugaan Pelanggaran Pasal 29 Undang-Undang Nomor 5 Tahun 1999 Juncto. Pasal 6 Peraturan Pemerintah Nomor 57 Tahun 2010 dalam Pengambilalihan Saham (Akuisisi) Perusahaan Woongjin Chemical Co. (Woongïn) oleh Toray Advanced Materials Korea Inc. (Toray Materials), Nomor 17/KPPU-M/2015

${ }^{23}$ Lihat ketentuan Pasal 5 ayat (2) Peraturan Pemerintah Nomor 57 Tahun 2010 tentang Penggabungan atau Peleburan Badan Usaha dan Pengambilalihan Saham Perusahaan yang dapat mengakibatkan terjadinya Praktik Monopoli dan Persaingan Usaha Tidak Sehat

24 Salinan Putusan Majelis Komisi Pengawas Persaingan Usaha Republik Indonesia, tentang Dugaan Pelanggaran Pasal 29 Undang-Undang Nomor 5 Tahun 1999 Juncto. Pasal 6 Peraturan Pemerintah Nomor 57 Tahun 2010 dalam Pengambilalihan Saham (Akuisisi) Perusahaan Woongjin Chemical Co. (Woongjin) oleh Toray Advanced Materials Korea Inc. (Toray Materials), Nomor 17/KPPU-M/2015, hlm. 70 
ketentuan perundang-undangan di Indonesia, khususnya dalam bidang persaingan usaha. Selain itu, Majelis KPPU juga berpendapat bahwa nilai aset dan nilai penjualan hasil tindakan akuisisi saham Woongjin oleh Toray Materials telah memenuhi jumlah tertentu sebagaimana yang diatur dalam Pasal 5 ayat (2) PP No. 57/2010.25 Berdasarkan hal tersebut Majelis KPPU menyimpulkan bahwa tindakan akuisisi saham Woongjin tersebut wajib dilaporkan/ diberitahukan kepada KPPU.26 Dengan kata lain, Majelis KPPU berpendapat bahwa mereka memiliki kewenagan terhadap tindakan akuisisi saham Woongjin.

Tindakan akusisi saham Woongin oleh Toray Materials dilakukan di Korea Selatan, karena Toray Materials sebagai pihak pengakuisisi dan Woongjin sebagai pihak yang diakuisisi merupakan perusahaan asing yang didirikan dan berkedudukan di Korea Selatan. ${ }^{27}$ Namun demikian, kedua perusahaan tersebut ternyata memiliki kegiatan usaha di Indonesia melalui perusahaan yang dikendalikannya. Toray Materials merupakan pemegang saham pengendali PT. Polytech Jakarta yang berkedudukan dan melakukan kegiatan usaha di Indonesia. ${ }^{28}$ Toray Materials memiliki 65\% saham PT. Polytech Jakarta. ${ }^{29}$ Adapun Woongjin, merupakan pemegang saham pengendali pada PT. Woongjin Textiles yang juga berkedudukan dan melakukan kegiatan usaha di Indonesia.

Menurut Peraturan KPPU Nomor 2 Tahun 2013 tentang Perubahan Ketiga atas Peraturan Komisi Pengawas Persaingan Usaha Nomor 13 Tahun 2010 tentang Pedoman Pelaksanaan Penggabungan atau Peleburan Badan Usaha dan Pengambilalihan Saham Perusahaan yang dapat Mengakibatkan terjadinya Praktik Monopoli dan Persaingan Usaha Tidak Sehat (Perkom No. 12/2013), tindakan akuisisi saham perusahaan yang dilakukan di luar wilayah Indonesia disebut dengan istilah pengambilalihan/akuisisi saham asing. Perkom No. 12/2010 menyatakan bahwa, Pengambilalihan asing yang terjadi di luar wilayah yurisdiksi Indonesia tidak menjadi perhatian Komisi selama tidak mempengaruhi kondisi

${ }^{25}$ Ibid., hlm. 72-73

${ }^{26}$ Ibid., hlm. 73

${ }^{27}$ Ibid., hlm. 13

${ }^{28}$ Ibid., hlm. 32

29 Skema Kepemilikan Toray Group Company Setelah Akusisi WJC yang terdapat dalam Salinan Putusan Majelis KPPU No. 17/KPPU-M/2015 menunjukkan bahwa Toray Materials memiliki saham PT Polytech Jakarta sebesar 65\%. 
persaingan domestik. ${ }^{30}$ Komisi memiliki wewenang dan akan melaksanakan kewenangannya terhadap Penggabungan, Peleburan dan Pengambilalihan tersebut seandainya Penggabungan, Peleburan dan Pengambilalihan tersebut mempengaruhi pasar domestik Indonesia dengan memperhatikan efektivitas pelaksanaan kewenangan yang dimiliki oleh Komisi. ${ }^{31}$

Pengambilalihan/akusisi saham asing yang menjadi kewenangan KPPU, serta wajib dilaporkan/diberitahukan kepada KPPU adalah akuisisi asing yang memenuhi faktor-faktor sebagai berikut: 32

1. pengambilalihan (akuisisi saham) dilakukan di luar yurisdiksi Indonesia;

2. berdampak langsung pada pasar Indonesia;

3. pengambilalihan (akuisisi saham) memenuhi batasan nilai; dan

4. pengambilalihan (akuisisi saham) antar perusahaan yang tidak terafiliasi.

Adapun yang dimaksud dengan berdampak langsung pada pasar Indonesia yaitu: 33

1. Seluruh pihak yang melakukan Penggabungan, Peleburan dan Pengambilalihan melakukan kegiatan usaha di Indonesia baik secara langsung maupun tidak langsung, misalnya melalui perusahaan di Indonesia yang dikendalikannya; atau

2. hanya satu pihak yang melakukan Penggabungan, Peleburan dan Pengambilalihan melakukan kegiatan usaha di Indonesia namun pihak lain di dalam Penggabungan, Peleburan dan Pengambilalihan memiliki penjualan ke Indonesia; atau

3. hanya satu pihak yang melakukan Penggabungan, Peleburan dan Pengambilalihan melakukan kegiatan usaha di Indonesia dan pihak lain yang melakukan Penggabungan, Peleburan dan Pengambilalihan tidak melakukan kegiatan, namun memiliki sister company yang memiliki kegiatan usaha di Indonesia

Ketentuan di atas dimaksudkan untuk menegaskan bahwa berlakunya UU No. 5/1999 beserta peraturan pelaksanaannya menganut prinsip territorial. Pasal 1 huruf e UU No. 5/1999 mengatur bahwa, "pelaku usaha adalah setiap orang perorangan atau badan usaha, baik yang berbentuk badan hukum atau bukan

${ }^{30}$ Lihat BAB IV Bagian D Peaturan KPPU Nomor 12 Tahun 2013 tentang Perubahan Ketiga atas Peraturan Komisi Pengawas Persaingan Usaha Nomor 13 Tahun 2010 tentang Pedoman Pelaksanaan Penggabungan atau Peleburan Badan Usaha dan Pengambilalihan Saham Perusahaan yang dapat Mengakibatkan terjadinya Praktik Monopoli dan Persaingan Usaha Tidak Sehat.

${ }^{31}$ Ibid.
${ }^{32}$ Ibid.
${ }^{33}$ Ibid. 
badan hukum yang didirikan dan berkedudukan atau melakukan kegiatan dalam wilayah hukum negara Republik Indonesia." Frasa yang berbunyi "yang didirikan dan berkedudukan dalam wilayah hukum negara Republik Indonesia" menunjukkan bahwa berlakunya UU No. 5/1999 menganut prinsip territorial subjektif, sedangkan frasa "melakukan kegiatan usaha dalam wilayah hukum negara Republik Indonesia" menunjukkan prinsip territorial objektif. ${ }^{34}$ Dengan demikian, dapat disimpulkan bahwa UU No. 5/1999 menganut prinsip territorial, artinya jangkauan berlakunya UU No. 5/1999 hanya dibatasi pada badan usaha yang didirikan dan berkedudukan, atau melakukan kegiatan usaha di wilayah negara Republik Indonesia. Berdasarkan prinsip territorial tersebut maka, kewajiban pelaku usaha untuk menyampaikan pemberitahuan/notifikasi tindakan akuisisi saham kepada KPPU tidak berlaku bagi merger (akusisi saham) crossborder (akuisisi saham yang dilakukan di luar wilayah yurisdiksi Indonesia), kecuali jika merger (akuisisi saham) tersebut dapat berdampak langsung pada pasar Indonesia. ${ }^{35}$

Tindakan korporasi berupa akuisisi saham Woongjin yang dilakukan oleh Toray Materials dilakukan di luar yurisdiksi Indonesia, yaitu di Korea Selatan, karena kedua perusahaan tersebut berkedudukan di Korea Selatan. Namun demikian, Toray Materials sebagai pihak pengakuisisi dan Woongjin sebagai pihak yang diakuisisi, keduanya memiliki kegiatan usaha di wilayah Indonesia melalui perusahaan yang dikendalikannya yang berkedudukan di Indonesia. Merujuk pada ketentuan di dalam Perkom No. 12/2013, tindakan korporasi berupa akusisi saham Woongiin tersebut memenuhi unsur pengambilalihan/akuisisi asing yang wajib dilaporkan/diberitahukan kepada KPPU. Tindakan akuisisi saham Woongjin dilakukan di luar yurisdiksi Indonesia, tetapi akuisisi tersebut dapat berdampak langsung pada pasar Indonesia, karena baik Toray Materials maupun Woongjin melakukan kegiatan usaha di Indonesia baik secara langsung maupun tidak langsung, misalnya melalui perusahaan di Indonesia yang dikendalikannya.

34 Ahmad Alfa Oktaviano dan Ditah Wiradiputra, "Dampak Prinsip Ekstrateritorial Terhadap Regulasi Merger, Konsolidasi, Dan AKuisisi Dalam Hukum Persaingan Usaha di Indonesia", http://www.lib.ui.ac.id/naskahringkas/2016-06/S56456-Ahmad\%20Alfa\%20Oktaviano diakses pada tanggal 28 September 2017

35 “PP No. 57 Tabun 2010 Dari Sudut Pandang Konseptor”, Media Berkala Komisi Pengawas Persaingan Usaha KOMPETISI, Edisi 24 Tahun 2010 
Berkaitan dengan jumlah nilai aset dan nilai penjualan gabungan, Majelis KPPU dalam pertimbangannya menyatakan bahwa, jumlah nilai aset dan nilai penjualan gabungan hasil akuisisi saham Woongjin yang dilakukan oleh Toray Materials mencapai Rp. 4.301.231.144.470,- untuk nilai aset dan Rp. 5.651.631.521.283,- untuk nilai penjualan. ${ }^{36}$ Jumlah nilai aset dan nilai penjualan gabungan tersebut dihitung berdasarkan penjumlahan antara nilai aset dan nilai penjualan Toray Materials, dan nilai aset dan nilai penjualan Woongjin. Selain itu, penghitungan nilai aset dan nilai penjualan hasil akuisisi tersebut mencakup pula nilai aset dan nilai penjualan perusahaaan-perusahaan yang terkait dengan kedua perusahaan tersebut yang berkedudukan di Indonesia.

Pada prinsipnya, penghitungan jumlah nilai aset dan/ atau nilai penjualan gabungan hasil akuisisi saham tidak hanya meliputi perusahaan pengakuisisi dan perusahaan yang diakuisisi. ${ }^{37}$ Penghitungan tersebut juga meliputi jumlah nilai aset dan/atau penjualan dari perusahaan yang terkait secara langsung dengan perusahaan yang melakukan akuisisi secara vertikal yaitu, induk perusahaan sampai dengan badan usaha induk tertinggi dan anak perusahaan yang paling bawah. $^{38}$

Berkaitan dengan hubungan afiliasi, Toray Materials dan Woongjin bukan perusahaan yang terafiliasi. Berdasarkan Penjelasan Pasal 7 PP No. 10/2010 yang dimaksud terafiliasi yaitu:

1. hubungan antara perusahaan, baik langsung maupun tidak langsung, mengendalikan atau dikendalikan oleh perusahaan tersebut;

2. hubungan antara 2 (dua) perusahaan yang dikendalikan, baik langsung maupun tidak langsung, oleh pihak yang sama; atau

3. hubungan antara perusahaan dan pemegang saham utama.

Sebelum dilakukannya tindakan akusisi, Toray Materials marupakan anak perusahaan dari Badan Usaha Induk Tertinggi yaitu Toray Indutries Inc. yang berkedudukan di Korea Selatan, sedangkan Woongjin merupakan anak perusahaan

36 Salinan Putusan Majelis Komisi Pengawas Persaingan Usaha Republik Indonesia, tentang Dugaan Pelanggaran Pasal 29 ..., Op. Cit., hlm. 72

${ }^{37}$ Rachmadi Usman, Hukum Persaingan..., Op. Cit., hlm. 648

38 Ibid., hlm. 649 
dari Badan Usaha Induk tertingginya yaitu Wooongjin Grup yang juga berkedudukan di Korea Selatan. Oleh karena itu, secara vertikal Toray Materials dan Woongjin dikendalikan oleh badan usaha induk tertinggi yang berbeda. Selain itu, antara Toray Materials dan Woongjin tidak memiliki hubungan perusahaan dalam bentuk dikendalikan atau mengendalikan. Berdasarkan hal tersebut, Toray Materials dan Woongjin bukanlah perusahaan yang terafiliasi. Dengan demikian pengambilalihan/akuisisi saham Woongjin ini telah memenuhi unsur pengambilalihan saham asing yang menjadi kewenangan KPPU yakni, pengambilalihan (akuisisi saham) antar perusahaan yang tidak terafiliasi.

Berdasarkan uraian di atas dapat disimpulkan, bahwa tindakan akuisisi saham Woongjin oleh Toray Materials merupakan pengambilalihan/ akusisi saham asing yang menjadi kewenangan KPPU, serta wajib untuk dilaporkan/ diberitahukan kepada KPPU. Dengan kata lain pihak Toray Materials sebagai pihak dalam transaksi akuisisi tersebut memiliki kewajiban hukum untuk menyampaikan pemberitahuan/ notifikasi tindakan akuisisi saham Woongjin yang dilakukannya tersebut.

Pertanggaungjawaban Hukum Toray Materials atas Keterlambatan Pemberitahuan/ Notifikasi Tindakan Akusisi Saham Woongjin kepada KPPU

Menurut Investigator KPPU, pengambilalihan saham Woongjin berlaku efektif secara hukum pada 28 Februari 2014 sejak Terlapor melakukan notifikasi pelaporan perubahan kepemilikan saham kepada Financial Supervisory Commision. ${ }^{39}$ Majelis KPPU dalam pertimbangan putusannya menilai bahwa tanggal efektif pengambilalihan/akuisisi saham Woongjin jatuh pada tanggal 3 Maret 2014. ${ }^{40}$ Oleh karena itu, Majelis KPPU berpendapat bahwa, batas akhir pelaporan tindakan akuisisi saham Woongjin adalah 30 hari (senin sampai dengan kamis) sejak tanggal berlaku efektif akuisisi, yang jatuh pada hari senin 14 April 2014.41 Adapun Toray Materials baru menyampaikan pemberitahuan pengambilalihan saham tersebut pada 21 April 2014. Dengan demikian, Toray

39 Salinan Putusan Majelis Komisi Pengawas Persaingan Usaha Republik Indonesia, tentang Dugaan Pelanggaran Pasal 29 ..., Op. Cit., hlm. 73

${ }^{40}$ Ibid., hlm. 75

${ }^{41}$ Ibid. 
Materials terlambat melakukan pemberitahuan pengambilalihan/ akuisisi saham Woongjin selama 4 hari. ${ }^{42}$

Berdasarkan pertimbangan di atas, Majelis KPPU memutuskan bahwa, Toray Materials terbukti secara sah dan meyakinkan melanggar Pasal 29 UU No. 5/1999 Juncto Pasal 6 PP No. 57/2010. Selain itu, Majelis KPPU memutuskan menghukum Toray Materials membayar denda sebesar Rp. 2.000.000.000,-..43 Dengan adanya Putusan Majelis KPPU tersebut, Toray Materials telah dinyatakan sah dan meyakinkan telah melakukan pelanggaran hukum di bidang persaingan usaha.

Perbuatan yang dilakukan oleh Toray Materials dalam ilmu hukum dapat dikatakan sebagai perbuatan melawan hukum, khusunya peraturan perundangundangan di bidang persaingan usaha. Pada prinsipnya Toray Materials tidak melaksanakan kewajiban hukumnya sebagaimana diatur dalam Pasal 29 UU No. 5/1999 juncto Pasal 6 PP No. 57/2010. Berkaitan dengan perbuatan melawan hukum, kata "perbuatan" dalam istilah perbuatan melawan hukum mengandung arti perbuatan aktif, dan juga perbuatan pasif. ${ }^{44}$ Perbuatan aktif dalam perbuatan melawan hukum dapat diartikan bahwa, orang dikatakan telah melakukan perbuatan melawan hukum apabila orang tersebut dengan sengaja melakukan suatu perbuatan, padahal menurut hukum harusnya ia tidak boleh melakukan perbuatan tersebut. Sebaliknya dalam arti perbuatan pasif, orang dikatakan melakukan perbuatan melawan hukum apabila orang yang bersangkutan dengan sengaja berdiam diri saja, padahal menurut hukum harusnya ia bertindak. ${ }^{45}$ Berdasarkan uraian tersebut, perbuatan yang dilakukan oleh Toray Materials dapat dikategorikan sebagai perbuatan melawan hukum pasif, karena ia tidak bertindak menyampaikan pemberitahuan/notifikasi tindakan akuisisi saham Woongjin, padahal menurut hukum dalam arti peraturan perundang-undangan seharusnya ia memiliki kewajiban untuk menyampaikan pemberitahuan tersebut.

\footnotetext{
${ }^{42}$ Ibid.

${ }^{43}$ Lihat Petitum angka 2 Salinan Putusan Majelis Komisi Pengawas Persaingan Usaha Republik Indonesia, tentang Dugaan Pelanggaran Pasal 29 Undang-Undang Nomor 5 Tahun 1999 Juncto. Pasal 6 Peraturan Pemerintah Nomor 57 Tahun 2010 dalam Pengambilalihan Saham (Akuisisi) Perusahaan Woongïn Chemical Co. (Woongjin) oleh Toray Advanced Materials Korea Inc. (Toray Materials), Nomor 17/KPPU-M/2015.

${ }^{44}$ Rosa Agustina, Perbuatan Melawan Hukum, Penerbit Program Pascasarjana FHUI, Jakarta, 2003, hlm. 7

45 M. A. Moegni Djojodirjo, Perbuatan Melawan Hukum, Penerbit Pradnya Paramita, Jakarta, 1982, hlm. 13
} 
Asas utama dalam pertanggungjawaban pidana adalah "geen straf zonder schuld" yang artinya harus adanya kesalahan pada pelaku. ${ }^{46}$ Oleh karena itu, dalam perbuatan melawan hukum, mengharuskan adanya unsur kesalahan pada diri pelaku. Berdasarkan undang-undang maupun yurisprudensi, setiap perbuatan pada dasarnya dapat masuk dalam kategori perbuatan melawan hukum apabila terdapat unsur kesalahan. ${ }^{47}$ Dalam pemeriksaan yang dilakukan oleh Majelis KPPU terhadap perkara pengambilalihan/akusisi saham Woongjin, Toray Materials sebagai pihak Terlapor menyatakan dalam kesimpulannya bahwa, keterlambatan pemberitahuan/ notifikasi tindakan akusisi saham Woongiin tersebut dikarenakan pihaknya tidak mempunyai informasi yang cukup tentang peraturan di Indonesia, khususnya terkait dengan adanya kewajiban untuk memberitahukan tindakan akusisi tersebut kepada KPPU. Dengan kata lain, pihak Toray Materials menyatakan bahwa keterlambatan pemberitahuan tindakan akuisisi saham Woongjin tersebut bukan suatu tindakan yang disengaja. Alasan tersebut pada dasarnya digunakan oleh Toray Materials untuk membuktikan bahwa keterlambatan pemberitahuan akuisisi tersebut bukan merupakan perbuatan melawan hukum, karena pada diri Toray Materials tidak ada kesalahaan dalam arti sempit yakni adanya kesengajaan untuk melakukan perbuatan tersebut.

Kesalahan dalam arti sempit hanya mencakup adanya unsur kesengajaan saja, sedangkan dalam arti luas, kesalahan mencakup tidak hanya adanya unsur kesengajaan tetapi juga adanya unsur kelalaian. Merujuk pada Lampiran Peraturan Komisi Pengawas Persaingan Usaha Nomor 4 Tahun 2009 tentang Pedoman Tindakan Administratif Sesuai Ketentuan Pasal 47 UU No. 5/1999 (Pedoman Pasal 47), terdapat ketentuan yang menyatakan bahwa, dalam menentukan sanksi administratif berupa denda, KPPU dapat mempertimbangkan keadaan yang menghasilkan penambahan atau pengurangan nilai dasar denda berdasarkan penilaian secara keseluruhan dengan tetap memperhatikan seluruh aspek-aspek yang terkait. Adapun pengurangan nilai dasar denda dapat dilakukan apabila ditemukan hal-hal yang meringankan yaitu:

${ }^{46}$ Nia Putriyana dan Shintiya Dwi Puspita, "Tanggungjawab Hukum Dalam Konteks Perbuatan Melawan Hukum Terhadap Tindak Pidana Korupsil”' artikel dalam Jurnal Arena Hukum, Nomor 3, Volume 7, Tahun 2014, hlm. 13

47 Wirjono Prodjodikoro, Perbuatan Melawan Hukum, Penerbit Mandar Maju, Bandung, 2000, hlm. 16 
1. Terlapor memberikan bukti bahwa dia telah menghentikan tindakan pelanggaran segera setelah KPPU melakukan penyelidikan.

2. Terlapor menunjukkan bukti bahwa pelanggarannya dilakukan secara tidak sengaja.

3. Terlapor menunjukkan bukti bahwa keterlibatannya adalah minimal.

4. Terlapor bersikap baik dan kooperatif dalam proses penyelidikan dan/atau pemeriksaan.

5. Apabila tindakan tersebut merupakan perintah perundang-undangan atau persetujuan instansi yang berwenang.

6. Adanya pernyataan kesediaan untuk melakukan perubahan perilaku dari pelaku usaha.

Point 2 menyatakan bahwa pengurangan nilai dasar denda dapat dilakukan apabila "Terlapor menunjukkan bukti bahwa pelanggarannya dilakukan secara tidak sengaja". Hal tersebut menunjukkan bahwa, konsep kesalahan yang dianut dalam perbuatan melawan hukum di bidang persaingan usaha adalah kesalahan dalam arti luas yakni, meliputi kesengajaan dan kelalaian. Dengan demikan, perbuatan seseorang yang melakukan pelanggaran hukum persaingan usaha karena kelalaiannya tetap dapat dikatakan sebagai perbuatan melawan hukum. Pada perbuatan melawan hukum dengan unsur kelalaian, pelaku tidak memiliki niat untuk menimbulkan akibat dari perbuatanya, bahkan mungkin terdapat keinginan untuk mencegah terjadinya akibat dari perbuatannya. ${ }^{48}$ Dalam hukum, suatu perbuatan dapat dianggap sebagai kelalaian apabila terdapat suatu perbuatan atau mengabaikan sesuatu yang mestinya dilakukan. ${ }^{49}$

Berdasarkan ketentuan Pasal 29 UU No. 5/1999 Juncto Pasal 5 ayat (2) PP No. 57/2010, Toray Materials memiliki kewajiban hukum untuk menyampaikan pemberitahuan akuisisi saham Woongjin yang dilakukannya kepada KPPU. Namun demikian, pemberitahuan tersebut ternyata terlambat dilakukan oleh Toray Materials selama 4 hari. Dengan demikian Toray Materials pada prinsipnya telah

${ }^{48}$ Munir Fuady, Perbuatan Melawan Hukum: Pendekatan Kontemporer, Penerbit Citra Aditya Bakti, Bandung, 2005, hlm. 73

${ }^{49}$ Ibid. 
mengabaikan kewajiban hukum yang semestinya dilakukannya. Namun pihak Toray Materials menyatakan bahwa keterlambatan tersebut dikarenakan dirinya tidak mempunyai informasi yang cukup tentang peraturan di Indonesia.

Suatu perbuatan dapat dikatakan pula sebagai kelalaian apabila terdapat suatu kewajiban kehati-hatian (duty of care), tetapi kehati-hatian tersebut tidak dijalankan. ${ }^{50}$ Toray Materials sebagai pihak pengakuisisi dan Woongjin sebagai pihak yang diakuisisi memiliki kegiatan usaha di Indonesia melalui perusahaan yang dikendaliknya. Bahkan badan usaha induk tertinggi dari Toray Materials yakni Toray Industries Inc., memiliki kegiatan usaha di Indonesia melalui perusahaanperusahaan yang dikendalikannya baik secara langsung maupun tidak langsung. Hal tersebut secara tidak langsung memberikan kewajiban bagi pihak Toray Materials untuk berhati-hati dalam melakukan setiap tindakan korporasi. Semestinya Toray Materials mencari informasi terkait seluruh regulasi baik yang bersifat territorial maupun ekstrateritorial yang berkaitan dengan tindakan akuisisi saham yang dilakukannya. Namun demikian, Toray Materials ternyata tidak menerapkan kehatihatian tersebut, yang kemudian mengakibatkan terjadinya pelanggaran terhadap ketentuan Pasal 29 UU No. 5/1999 Juncto Pasal 6 PP No. 57/2010.

Berdasarkan uraian di atas, keterlambatan pemberitahuan akuisisi saham yang dilakukan oleh Toray Materials merupakan perbuatan melawan hukum, karena memenuhi unsur kesalahan. Kesalahan yang dilakukan oleh Toray Materials merupakan kesalahan dalam bentuk kelalain yang mengakibatkan terjadinya pelanggaran terhadap ketentuan dalam hukum persaingan usaha. Dalam hukum, dikenal adanya prinsip pertanggung jawaban berdasarkan unsur kesalahan. Prinsip tersebut menyatakan bahwa, seseorang baru dapat dimintakan pertanggung jawabannya secara hukum jika ada unsur kesalahan yang dilakukannya. ${ }^{51}$ Merujuk pada prinsip tersebut maka, Toray Materials memiliki pertanggung jawaban secara hukum atas perbuatannya. Pertanggung jawaban tersebut berupa penjatuhan sanksi tindakan administratif berupa denda sebagimana diputuskan oleh Majelis KPPU.

\footnotetext{
${ }^{50}$ Ibid.

51 Shidharta, Hukum Perlindungan Konsumen Indonesia, Penerbit Gramedia Widiasarana Indonesia, Jakarta, 2006, hlm. 73-79
} 


\section{Penutup}

Kewajiban menyampaikan pemberitahuan/notifikasi tindakan akuisisi saham kepada KPPU tidak berlaku bagi akuisisi saham yang dilakukan di luar wilayah yurisdiksi Indonesia, kecuali jika akuisisi saham tersebut dapat berdampak langsung pada pasar Indonesia. Tindakan akuisisi saham Woongjin yang dilakukan oleh Toray Materials merupakan pengambilalihan asing sebagaimana yang dimaksud dalam yang masuk ke dalam kategori pengambilalihan/ akusisi asing Perkom No. 12/2013. Tindakan akuisisi tersebut memenuhi kriteria pengambilalihan/ akuisisi saham asing sebagaimana yang diatur dalam Perkom No. 12/2013. Oleh karena itu, tindakan akusisi saham Woongjin oleh Toray Materials wajib diberitahukan kepada KPPU, atau dengan kata lain KPPU memiliki kewenangan terhadap akuisisi saham Woongjin tersebut.

Konsep kesalahan yang dianut dalam perbuatan melawan hukum di bidang persaingan usaha adalah kesalahan dalam arti luas yakni, meliputi kesengajaan dan kelalaian. Dengan demikan, pelanggaran hukum persaingan usaha karena kelalaian tetap dapat dikatakan sebagai perbuatan melawan hukum. Keterlambatan pemberitahuan akuisisi saham yang dilakukan oleh Toray Materials merupakan perbuatan melawan hukum, karena memenuhi unsur kesalahan. Kesalahan yang dilakukan oleh Toray Materials merupakan kesalahan dalam bentuk kelalain yang mengakibatkan terjadinya pelanggaran terhadap ketentuan dalam hukum persaingan usaha. Merujuk pada prinsip pertanggung jawaban berdasarkan unsur kesalahan, Toray Materials memiliki pertanggung jawaban secara hukum atas perbuatannya. Pertanggung jawaban tersebut berupa penjatuhan sanksi tindakan administratif berupa denda sebagaimana yang diputuskan oleh Majelis KPPU.

\section{Daftar Pustaka}

\section{Buku}

Agustina, Rosa, Perbuatan Melawan Hukum, Cetakan Pertama, Program Pascasarjana FHUI, Jakarta, 2003. 
Djojodirjo, M. A. Moegni. Perbuatan Melawan Hukum. Cetakan Kedua, Pradnya Paramita, Jakarta ,1982.

Fuady, Munir. Perbuatan Melawan Hukum: Pendekatan Kontemporer, Cetakan Pertama, Citra Aditya Bakti, Bandung, 2005.

Harahap, M. Yahya. Hukum Perseroan Terbatas, Cetakan Kelima, Sinar Grafika, Jakarta, 2015.

Lubis, Andi Fahmi et. al. Hukum Persaingan Usaha Antara Teks \& Konteks. Oktober 2009, Komisi Pengawas Persaingan Usaha (KPPU), Jakarta, 2009.

Nugroho, Susanti Adi. Hukum Persaingan Usaha Di Indonesia, Dalam Teori Dan Praktik Serta Penerapan Hukumnya, Edisi Pertama, Cetakan Pertama, Kencana, Jakarta, 2012.

Prodjodikoro, Wirjono. Perbuatan Melawan Hukum, Cetakan Pertama, Mandar Maju, Bandung, 2000.

Shidharta. Hukum Perlindungan Konsumen Indonesia, Edisi Revisi, Gramedia Widiasarana Indonesia, Jakarta, 2006.

Usman, Rachmadi. Hukum Persaingan Usaha Di Indonesia, Cetakan Pertama, Sinar Grafika, Jakarta, 2013.

\section{Jurnal}

Putriyana, Nia dan Shintiya Dwi Puspita. "Tanggungjawab Hukum Dalam Konteks Perbuatan Melawan Hukum Terhadap Tindak Pidana Korupsi" artikel dalam Jurnal Arena Hukum, Nomor 3, Volume 7, Tahun 2014.

\section{Peraturan Perundang-undangan:}

Undang-Undang Republik Indonesia Nomor 5 Tahun 1999 tentang Larangan Praktek Monopoli dan Persaingan Usaha Tidak Sehat.

Peraturan Pemerintah Republik Indonesia Nomor 57 Tahun 2010 tentang Penggabungan atau Peleburan Badan Usaha dan Pengambilalihan Saham Perusahaan yang dapat mengakibatkan terjadinya Praktik Monopoli dan Persaingan Usaha Tidak Sehat.

Peraturan KPPU Nomor 2 Tahun 2013 tentang Perubahan Ketiga atas Peraturan Komisi Pengawas Persaingan Usaha Nomor 13 tahun 2010 Tentang Pedoman Pelaksanaan Penggabungan atau Peleburan Badan Usaha dan Pengambilalihan Saham Perusahaan yang dapat Mengakibatkan terjadinya Praktik Monopoli dan Persaingan Usaha Tidak Sehat.

Peraturan Komisi Pengawas Persaingan Usaha Nomor 4 Tahun 2009 tentang Pedoman Tindakan Administratif Sesuai Ketentuan Pasal 47 UU Nomor 5 Tahun 1999.

\section{Putusan Komisi Pengawas Persaingan Usaha}

Salinan Putusan Majelis Komisi Pengawas Persaingan Usaha Republik Indonesia, tentang Dugaan Pelanggaran Pasal 29 Undang-Undang Nomor 5 Tahun 1999 Juncto. Pasal 6 Peraturan Pemerintah Nomor 57 Tahun 2010 dalam 
Pengambilalihan Saham (Akuisisi) Perusahaan Woongjin Chemical Co. oleh Toray Advanced Materials Korea Inc., Nomor 17/KPPU-M/2015.

\section{Surat Kabar}

"Pemberlakuan Peraturan Pemerintah No.57/2010 tentang Merger dan Akuisisi", dalam Media Berkala Komisi Pengawas Persaingan Usaha KOMPETISI, Edisi 23 Tahun 2010.

"PP No. 57 Tahun 2010 Dari Sudut Pandang Konseptor", dalam Media Berkala Komisi Pengawas Persaingan Usaha KOMPETISI, Edisi 24 Tahun 2010.

\section{Website}

Ahmad Alfa Oktaviano dan Ditah Wiradiputra, Dampak Prinsip Ekstrateritorial Terhadap Regulasi Merger, Konsolidasi, Dan AKuisisi Dalam Hukum Persaingan Usaha di Indonesia, http://www.lib.ui.ac.id/naskahringkas/201606/S56456-Ahmad\%20Alfa\%20Oktaviano, diakses pada tanggal 28 September 2017.

"Toray Advanced tetap Dihukum Denda $\operatorname{Rp} 2 \mathrm{M}$ ke KPPU", http:/ / nasional.kontan.co.id/news/toray-advanced-tetap-dihukumdenda-rp-2-m-ke-kppu diakses pada tanggal 27 September 2017.

Pradana, Rio Sandy. "Didenda, Toray Gugat KPPU", http:/ / koran.bisnis.com/read/20161021/439/594567/didenda-toraygugat-kppu diakses pada tanggal 27 September 2017

"Siaran Pers Pembacaan Putusan Perkara Nomor 17/KPPU-M/2015", http:/ / www.kppu.go.id/id/blog/2016/03/siaran-pers-pembacaanputusan-perkara-nomor-17kppu-m2015/, diakses pada tanggal 27 September 2017. 